\title{
PENGEMBANGAN VARIASI LATIHAN KOMBINASI PASSING DAN SMASH DALAM BOLA VOLI
}

\author{
Basyaruddin Daulay dan Samri Saldi Daulay \\ Dosen Prodi Pendidikan Kepelatihan Olahraga, FIK Unimed \\ Email: badayfik@gmail.com
}

\begin{abstract}
ABSTRAK
Penelitian ini bertujuan untuk mengembangkan variasi latihan kombinasi passing dan smash pada bola voli 2016. Populasi dalam penelitian ini adalah pemain bola voli yang berasal dari tiga Club Bola Voli yang ada di kota Medan, yaitu Club Bola Voli TVRI Sumut, Club Bola Voli Gaperta Medan dan Club Bola Voli Mulia Medan. Variasi yang telah dibuat terlebih dahulu divalidasi 3 orang ahli, 1 orang merupakan pelatih yang berasal dari Club Bola Voli TVRI Sumut, 1 orang merupakan akademisi olahraga yang berasal dari Universitas Negeri Medan yang mempunyai latar belakang pendidikan olahraga, dan 1 orang merupakan ahli Bahasa yang biasa melakukan editing tulisan. Uji kelompok kecil melibatkan 10 orang pemain bola voli dan uji kelompok besar melibatkan 20 orang pemain bola voli. Variasi latihan kombinasi passing dan smash pada bola voli berjumlah 9 variasi. Hasil dari validasi ahli 9 variasi tersebut valid dan dapat digunakan untuk meningkatkan kemampuan passing bola voli dimana persentase validitasnya adalah 72\%-88\%. Hasil uji kelompok kecil terhadap 20 orang pemain menunjukkan bahwa 9 variasi tersebut sudah memenuhi kriteria layak atau valid. Persentase validitas dari angket yang telah dibagikan kepada sampel menunjukkan bahwa 98\%-100\% mereka mengakui bahwa variasi tersebut sudah memenuhi kriteria untuk meningkatkan kemampuan passing dan smash dalam permainan bola voli. Hasil uji kelompok besar terhadap 20 orang pemain bola voli menunjukkan bahwa 9 model tersebut sudah memenuhi kriteria layak digunakan. Persentase validitas dari angket yang telah dibagikan kepada sampel menunjukkan bahwa 100\% mereka mengakui bahwa variasi tersebut sudah memenuhi kriteria untuk meningkatkan kemampuan passing dan smash dalam permainan bola voli. Dapat disimpulkan kesembilan variasi tersebut baik untuk meningkatkan kemampuan passing dan smash dalam permainan bola voli dan pada setiap variasi sangat penting untuk dilakukan dalam latihan agar latihan tersebut tidak membosankan.
\end{abstract}

\section{Kata Kunci: Variasi Latihan, Smash, Passing, Bola Voli}

\section{PENDAHULUAN}

Olahraga merupakan sebuah aktifitas fisik yang mana tujuan dari berolahraga adalah mencapai prestasi setinggi-tingginya dengan semaksimal mungkin bagi mereka baik yang dia dalam individu maupun tim. Untuk mendapatkan prestasi dibidang olahraga yang digeluti diharapkan mendapat ilmu pengetahuan dan teknologi yang kegunaannya tepat.

Kemajuan dan perkembangan permainan bola Voli yang terjadi saat ini sangatlah baik untuk itu diharapkan agar banyak yang memberikan kontribusi dalam pengembangan, penciptaan temuan-temuan baru yang berupa bentuk-bentuk latihan yang lebik baik untuk kedepannya meliputi aspek fisik, teknik, dan taktik/strategi serta mental. Sehingga setiap masalah yang akan dihadapi dapat diatasidengan terus membenahi diri, dengan cara mengembangkan,mengevaluasi dan memperbaiki dari segala sektor pendukung serta terus mencari metode dan teknik yang lebih efektif dan efesien agar dapat menghasilkan atlet yang prestasinya lebih baik dan akhirnya memperoleh tim yang lebih berprestasi.

Club bola Voli TVRI merupakan salah satu club yang sudah mempunyai pengalaman di dalam bidang bola Voli yang bertujuan untuk mencari dan membina bibitbibit pemain bola Voli yang handal khususnya generasi-generasi muda dan pemula, club bola Voli TVRI bertempat 
latihan di Jalan Putri Hijau Medan Kota yang dilatih oleh 3 pelatih yaitu Sugianto Asta, Robi Andi Syafutra dan Andi. Club bola Voli TVRI memiliki pasilitas yang lengkap : lapangan bola Voli, cone, net dan alat-alat latihan pendukung lainnya.

Pernyataan pelatih dari hasil wawancara pelatih dengan peneliti mendapatkan pernyataan bahwa dalam berlatih juga menerapkan variasi latihan biasa seperti yang dilakukan di Club bola Voli TVRI, hanya saja ditambahkan dengan sedikit menerima passing. Pelatih beranggapan bahwa fokus utama adalah latihan fisik dan menerapkan latihan drill, passing dan smash langsung pada saat bertanding, sehingga waktu latihan tidak terbuang untuk melakukan banyak variasi latihan passing dan smash.

Pengamatan peneliti yang keiga pada tanggal 20 Januari 2017 di club bola voli Mulia Medan. club bola voli Mulia medan merupakan suatu wadah untuk berlatih atlet bola voli di Kota Medan. dimana latihannya sudah bagus dan tersusun dikarenakan club bola voli Mulia dilatih oleh pelatih yang berpengalaman, Namun peneliti juga melihat bahwa variasi latihan passing dan smash yang digunakan pada saat latihan masih sedikit.

Dari ungkapan-ungkapan di atas maka peneliti melakukan analisis kebutuhan. Setelah penulis melakukan analisis kebutuhan kepada atlet didapatkan informasi $100 \%$ atlet memahami penguasaan latihan passing dan smash akan sangat mendukung pencapaian prestasi yang tinggi. 30\% yang menyatakan kesulitan dalam melakukan latihan passing. $50 \%$ yang menyatakan kesulitan dalam melakukan latihan smash. $100 \%$ atlet menginginkan dapat menguasai berbagai variasi latihan passing dan smash yang baik. $100 \%$ atlet menyatakan perlunya variasi latihan passing dan smash untuk dimasukkan dalam program latihan. Selanjutnya dilakukan membuat pernyataan kepada para pelatih dan atlet, hasil dari pernyataan tersebut telah dicantumkan dalam lampiran.

Hasil yang dikemukakan diatas akan dapat memperkuat peneliti untuk mengambil kesimpulan bahwa, perlu dikembangkan variasi latihan kombinasi passing dan smash, yang nantinya diharapkan dapat menjadi solusi untuk meningkatkan kemampuan passing dan smash bola Voli sehingga diharapkan dapat mempertinggi prestasi atlet bola Voli.

\section{KAJIAN TEORITIS \\ 1. Hakikat Latihan}

Pengertian latihan yang berasal dari kata training adalah suatu proses penyempurnaan kemampuan berolahraga yang berisikan meteri teori dan praktik, menggunakan metode, dan aturan pelaksanaan dengan pendekatan ilmiah, memakai prinsip-prinsip latihan yang terencana dan teratur, sehingga tujuan latihan dapat tercapai tepat pada waktunya. Salah satu ciri dari latihan baik yang berasal dari kata practice, exercise, dan training adalah beban latihan.Beban latihan oleh pelatih maupun atlet untuk memperbaiki kualitas fungsional berbagai peralatan tubuh.

Tujuan latihan secara umum adalah membantu para pembina, pelatih, agar dapat menerapkan dan memiliki kemampuan konseptual serta keterampilan dalam membantu mengungkapkan potensi atlet mencapai puncak prestasi.Sedangkan sasaran latihan secara khusus adalah untuk meningkatkan kemampuan dan kesiapan atlet dalam mencapai puncak prestasi.

\section{Hakikat Bola Voli}

Bola voli merupakan olahraga permainan yang dilakukan oleh dua tim atau regu yang saling berlawanan. Setiap regu hanya memiliki pemain yaitu 6 orang dalam sebuah pertandingan dan dapat digantikan oleh pemain cadangan jika pemain inti mengalami cidera ataupun permainan tidak sesuai dengan yang diharapkan. Permainan bola voli dimainkan menggunakan satu bola dipantulkan dari satu pemain ke pemain lain dengan cara passing yang diakhiri dengan smash pada tim lawan, dan untuk kedua tim dipisahkan oleh net dengan ketinggian tertentu (Muhyi:2008).

\section{Hakikat Teknik Dasar Bola Voli}

Suharno HP (1981: 35). Dalam mempertinggi bermain bolavoli, teknik dasar 
harus dipelajari terlebih dahulu karena teknik dasar merupakan pondasi dari proses gerak yang mampu meningkatkan keterampilan gerak yang bermutu tinggi. Serta untuk mengembangkan mutu prestasi permainan bola voli dan juga merupakan salah satu unsur yang menentukan menang atau kalah suatu tim di dalam pertandingan disamping unsur kondisi fisik, taktik dan mental.

\section{Hakikat Passing}

Passing adalah upaya seorang pemain dengan menggunakan suatu teknik tertentu untuk mengoperkan bola yang dimainkannya kepada teman seregunya untuk dimainkan di lapangan sendiri (Nuril Ahmadi, 2007:22). Ditambahkan (M. Yunus, 1992:79) menjelaskan bahwa passing adalah mengoper bola kepada teman satu regu dengan suatu teknik tertentu, sebagai langkah awal untuk menyusun pola serangan kepada lawan..

\section{Hakikat Passing bawah}

Passing bawah menurut (Nuril Ahmadi 2007:23) adalah teknik memainkan bola dengan sisi lengan bawah bagian dalam baik dengan menggunakan satu atau pun dua lengan secara bersamaan. Kegunaan dari passing bawah bola voli antara lain adalah untuk menerima bola servis, menerima bola smash atau serangan dari lawan, untuk menyelamatkan bola atau pantulan dari net, untuk menyelamatkan bola yang terpantul keluar menjauhi lapangan permainan dan untuk mengambil bola rendah yang datang secara tiba-tiba.

\section{Hakikat Passing Atas}

Menurut (Nuril Ahmad 2007:26-27) memainkan bola dengan teknik passing atas dapat dilakukan dengan berbagai variasi yaitu antra lain a) passing atas ke arah belakang lewat atas kepala, b) passing atas ke arah samping pemain, c) passing atas sambi melompat ke atas, d) passing atas sambil menjatuhkan diri ke samping, e) passing atas sambil menjatuhkan diri ke atas.

\section{Hakikat Smash}

Smash adalah pukulan yang utama dalam penyerangan dalam upaya meraih kemenangan (M. Yunus, 1992: 108). Selanjutnya Soeharno HP (1982:16) menjelaskan bahwa tehnik smash digolongkan menjadi open smash / normal smash, semi smash, quick smash, pushsmash, dan pool straight smash. Permainan bolavoli merupakan permainan cepat, ini dapat dilihat antara penyerangan dengan pertahanan sangat tidak seimbang. Penyerangan sangat tinggi tingkat keberhasilannya, sedangkan pertahanan sangat rendah. Hal ini terbukti dengan adanya peraturan baru tentang system rally point (game 25) jadi tidak ada regu yang akan memilih servis terlebih dahulu, kalaupun ada itu karena pertahanan tim sanggup untuk menghasilkan point. Menurut Viva Pakarindo (2006 :08), Smash atau spike adalah tindakan memukul bola ke lapangan lawan ketika pertandingan sedang berlangsung. Pukulan ini harus melewati atas net dan membuat lawan sulit untuk mengembalikan bola. Smash merupakan suatu teknik yang memiliki gerakan yang terdiri dari: a) Langkah awal; b) Tolakan; c.) Memukul bola pada saat di udara, dan d) Saat mendarat.

\section{METODOLOGI PENELITIAN}

Penelitian dan pengembangan merupakan penelitian yang bertujuan untuk menghasilkan produk, yang berupa bentuk latihan passing dan smash pada bola Voli yang baru. Sugiyono (2010: 297) "metode penelitian dan pengembangan adalah metode penelitian yang digunakan untuk menghasilkan produk tertentu, dan menguji keefektifan produk tersebut supaya berfungsi di masyarakat luas". Tempat penelitian direncanakan akan dilaksanakan dimasingmasing tempat latihan club atau ekstrakurikuler berlatih. Dalam pelaksanaannya penelitian ini memiliki sasaran sebagai berikut: (1) Pada uji coba tahap I (kelompok kecil) disarankan dapat melibatkan subyek sebanyak-banyaknya 10 orang, sekurang-kurangnya 8 orang dan di tiga club. Dalam penelitian ini peneliti melibatkan pada uji coba kelompok kecil berjumlah 10 orang, dari atlet Club bola Voli TVRI Sumut, 10 orang Club bola Voli Mulia, dan 10 orang Club bola Voli Gaperta, dan (2) Pada uji coba tahap II (kelompok besar) 
dalam penelitian ini peneliti melibatkan sebanyak 20 atlet yang masih aktif berlatih di Kota Medan. Sasaran penelitian atau pengguna yang menjadi sasaran dalam penelitian variasi latihan passing dan smash bola Voli adalah atlet club bola Voli TVRI Sumut, club bola Voli Gaperta, club bola Voli Mulia, Medan, Sumatera Utara.

Metode yang digunakan pada penelitian ini adalah penelitian pengembangan yang mencakup mengembangankan produk, menguji keefektifan produk untuk mencapai tujuan yang diinginkan.

Pengumpulan data yang digunakan pada pengembanganvariasi latihan kombinasi passing dan smash dalam olahraga bola voli adalah data kualitatif, karena data yang didapatkan dinyatakan dengan kalimat bukan dengan angka. Sedangkan data kuantitatif diperoleh dengan cara mengubah data kualitatif menjadi data kuantitatif dengan jalan memberikan skor pada data kualitatif tersebut. Instrumen yang digunakan pada penelitian pengembangan ini adalah dengan menggunakan angket untuk analisa kebutuhan, kuesioner dari evaluasi ahli/pelatih bola voli dan ahli olahraga serta dari hasil pendapat atlet (tahap uji coba 1 dan uji coba tahap II). Instrumen identifikasi kebutuhan dalam penelitian ini disusun dengan tujuan untuk mengumpulkan data pendapat pelatih terhadap bentuk latihan yang sudah dan sedang mereka gunakan dalam latihan, dan bentuk latihan seperti apa yang mereka inginkan. Instrumen ini juga didasarkan pada konsep tentang evaluasi bentuk latihan.Instrumen uji lapangan awal dan utama disusun melalui konsep evaluasi dari atlet. Teknik analisa data digunakan dengan teknik analisa deskriptif kuantitatif dengan persentase.

\section{HASIL DAN PEMBAHASAN}

\section{Hasil Penelitian}

Bola voli merupakan olahraga permainan yang dilakukan oleh dua tim atau regu yang saling berlawanan. Setiap regu hanya memiliki pemain yaitu 6 orang dalam sebuah pertandingan dan dapat digantikan oleh pemain cadangan jika pemain inti mengalami cidera ataupun permainan tidak sesuai dengan yang diharapkan. Permainan bola voli dimainkan menggunakan satu bola dipantulkan dari satu pemain ke pemain lain dengan cara passing yang diakhiri dengan smash pada tim lawan, dan untuk kedua tim dipisahkan oleh net dengan ketinggian tertentu

Passing merupakan teknik dasar dalam permainan sepak bola. Setiap pemain bola voli harus memiliki kemampuan dalam melakukan teknik passing tersebut. Passing dalam permainan bola voli upaya seorang pemain dengan menggunakan suatu teknik tertentu untuk mengoperkan bola yang dimainkannya kepada teman seregunya untuk dimainkan di lapangan sendiri (Nuril Ahmadi, 2007:22).

Dari observasi peneliti terhadap beberapa klub bola voli yang ada di kota Medan peneliti mengetahui seberapa besar kebutuhan pemain bola voli tentang bentuk latihan kombinasi passing dan smash dengan cara pengumpulan data melalui angket yang dimana peneliti melakukan pengumpulan data terhadap 20 orang pemain dari beberapa klub bola voli di kota Medan sehinggah diperoleh $100 \%$ pemain mengatakan bahwa mereka menyukai latihan di sekolah sepak bola yang saat ini menjadi tempat mereka latihan sepak bola dan $100 \%$ mereka suka latihan passing dan smash, $100 \%$ dari mereka cukup terampil dalam melakukan passing dan smash, $100 \%$ mereka tertarik melakukan latihan kombinasi passing dan smash, dan $100 \%$ mereka ingin mendapatkan bentuk variasi latihan kombinasi passing dan smash yang baru.

Pengujian pertama dilakukan setelah desain awal ataupun pengembangan variasi latihan kombinasi passing dan smash telah diamati, dikoreksi dan dinyatakan layak untuk diujicobakan oleh para ahli. Pengujian pertama terhadap model kombinasi latihan yang terdiri dari 3 orang ahli yaitu 1 orang pelatih, 1 orang akademisi olahraga, dan 1 orang ahli bahasa. Hasil evaluasi yang dilakukan ahli mengacu terhadap indikator yang telah disusun sebelumnya dimana menjadi acuan untuk menguji apakah model tersebut layak untuk digunakan atau tidak.

\section{a. Hasil Pengujian Tahap Pertama}

Dari hasil uji kelompok kecil dilakukan setelah pakar mengevaluasi produk yang telah dibuat oleh peneliti. Uji kelompok kecil dilakukan terhadap pemain dengan jumlah 20 orang sampel diperoleh kesimpulan bahwa :

1) $100 \%$ pemain pada uji kelompok kecil mengatakan bahwa Variasi latihan 1 (Segitiga Left) mudah dilakukan dan dilaksanakan dimana variasi tersebut juga menarik dan tidak membosankan. 
2) $100 \%$ pemain pada uji kelompok kecil mengatakan bahwa Variasi latihan 2 (Left Fake Passing \& Spike) mudah dilakukan dan dilaksanakan dimana variasi tersebut juga menarik dan tidak membosankan.

3) $98 \%$ pemain pada uji kelompok kecil mengatakan bahwa Variasi latihan 3 (Back Passing, Spike) mudah dilakukan dan dilaksanakan dimana variasi tersebut juga menarik dan tidak membosankan.

4) $98 \%$ pemain pada uji kelompok kecil mengatakan bahwa Variasi latihan 4 (Passing, Run Right, dan Fake Spiek) mudah dilakukan dan dilaksanakan dimana variasi tersebut juga menarik dan tidak membosankan.

5) $98 \%$ pemain pada uji kelompok kecil mengatakan bahwa Variasi latihan 5 (Passing, Run Left dan Fake Spike) mudah dilakukan dan dilaksanakan dimana variasi tersebut juga menarik dan tidak membosankan.

6) $98 \%$ pemain pada uji kelompok kecil mengatakan bahwa Variasi latihan 6 ((L) Passing, Spike) mudah dilakukan dan dilaksanakan dimana variasi tersebut juga menarik dan tidak membosankan.

7) $100 \%$ pemain pada uji kelompok kecil mengatakan bahwa Variasi latihan 7 (Passing, Run, Spike) mudah dilakukan dan dilaksanakan dimana variasi tersebut juga menarik dan tidak membosankan.

8) $98 \%$ pemain pada uji kelompok kecil mengatakan bahwa Variasi latihan 8 (Segitiga Rigth) mudah dilakukan dan dilaksanakan dimana variasi tersebut juga menarik dan tidak membosankan.

9) $98 \%$ pemain pada uji kelompok kecil mengatakan bahwa Variasi latihan 9 (Passing Back, Run, Spiek) mudah dilakukan dan dilaksanakan dimana variasi tersebut juga menarik dan tidak membosankan.

Dari hasil uji coba kelompok kecil pada pemain dimana setelah melakukan setiap variasi latihan passing simulasi game dimana para pemain diberikan angket untuk diisi sesuai pemahaman dia sendiri. Dari hasil uji coba kelompok kecil terhadap 20 orang pemain disimpulkan bahwa variasi latihan passing simulasi game dengan jumlah 9 variasi sudah memenuhi kriteria untuk dilanjutkan dalam uji coba kelompok besar karena persentase dari setiap model antara 98\%-100\%.

\section{b. Hasil Pengujian Tahap Kedua}

Setelah uji coba kecil dilaksanakan maka dilakukan uji coba kelompok besar. Hasil uji kelompok besar dilakukan terhadap pemain dengan jumlah 30 orang sampel diperoleh kesimpulan bahwa:

1) $100 \%$ pemain pada uji kelompok kecil mengatakan bahwa Variasi latihan 1 (Segitiga Left) mudah dilakukan dan dilaksanakan dimana variasi tersebut juga menarik dan tidak membosankan.

2) $100 \%$ pemain pada uji kelompok kecil mengatakan bahwa Variasi latihan 2 (Left Fake Passing \& Spike) mudah dilakukan dan dilaksanakan dimana variasi tersebut juga menarik dan tidak membosankan.

3) $100 \%$ pemain pada uji kelompok kecil mengatakan bahwa Variasi latihan 3 (Back Passing, Spike) mudah dilakukan dan dilaksanakan dimana variasi tersebut juga menarik dan tidak membosankan.

4) $100 \%$ pemain pada uji kelompok kecil mengatakan bahwa Variasi latihan 4 (Passing, Run Right, dan Fake Spiek) mudah dilakukan dan dilaksanakan dimana variasi tersebut juga menarik dan tidak membosankan.

5) $100 \%$ pemain pada uji kelompok kecil mengatakan bahwa Variasi latihan 5 (Passing, Run Left dan Fake Spike) mudah dilakukan dan dilaksanakan dimana variasi tersebut juga menarik dan tidak membosankan.

6) $100 \%$ pemain pada uji kelompok kecil mengatakan bahwa Variasi latihan 6 ((L) Passing, Spike) mudah dilakukan dan dilaksanakan dimana variasi tersebut juga menarik dan tidak membosankan.

7) $100 \%$ pemain pada uji kelompok kecil mengatakan bahwa Variasi latihan 7 (Passing, Run, Spike) mudah dilakukan dan dilaksanakan dimana variasi tersebut juga menarik dan tidak membosankan.

8) $100 \%$ pemain pada uji kelompok kecil mengatakan bahwa Variasi latihan 8 (Segitiga Rigth) mudah dilakukan dan dilaksanakan dimana variasi tersebut juga menarik dan tidak membosankan.

9) $100 \%$ pemain pada uji kelompok kecil mengatakan bahwa Variasi latihan 9 (Passing Back, Run, Spiek) mudah dilakukan dan dilaksanakan dimana variasi tersebut juga menarik dan tidak membosankan.

Dari hasil uji coba kelompok besar pada pemain dimana setelah melakukan setiap variasi latihan passing simulasi game dimana para pemain diberikan angket untuk diisi sesuai pemahaman dia sendiri. Dari hasil uji coba kelompok besar terhadap 30 orang pemain disimpulkan bahwa variasi latihan passing simulasi game dengan jumlah 9 variasi sudah memenuhi kriteria untuk dilanjutkan dalam 
pembuatan produk massal karena persentase dari setiap model antara $100 \%$.

\section{Pembahasan Produk}

Pengembangan produk ini bertujuan untuk meningkatkan kemampuan passing dan smash yang telah didapatkan selama ini. Variasi ini diperuntukkan bagi atlet yang telah menguasai teknik dasar passing dan smash, variasi ini kurang cocok apabila digunakan pada atlet pemula yang baru belajar bermain bola voli. Variasi yang dikembangkan ini masih tahap dasar dari variasi bermain itu sendiri, dikarenakan perlu adanya latihan dasar untuk melakukan variasi passing dan smash itu sendrir. Variasi ini didasari adanya kebutuhan untuk dapat meningkatkan kemampuan passing dan smash yang lebih baik dan pengayaan pengalaman dalam bentuk variasi-variasi latihan yang lebih banyak lagi serta diharapkan dapat memberi peran yang berarti untuk pencapaian prestasi yang lebih tinggi baik secara individu mau pun secara tim.

\section{KESIMPULAN}

Berdasarkan hasil dari uji coba lapangan dan hasil pembahasan peneliti, maka dapat disimpulkan bahwa : (1) Dalam melakukan latihan passing dan smash hendaknya latihan harus efektif dan efisien dalam meningkatkan kemampuan teknik dasar permainan bola voli khususnya passing dan smash, baik bagi pemain pemula maupun yang lanjutan. (2) Latihan passing dan smash hendaknya makin lebih menarik atau tidak membosankan untuk dilakukan, sehingga dapat membuat pemain akan bersungguhsungguh dan termotivasi untuk melakukan latihan serta mencapai tujuan latihan itu sendiri. (3) Dengan pengembangan variasi latihan kombinasi passing dan smash dalam permainan bola voli dapat bermanfaat untuk digunakan dalam meningkatkan kemampuan dasar bola voli khususnya passing dan smash di berbagai club bola voli yang ada di Indonesia, khusunya Sumatera Utara. Sedangkan beberapa rekomendasi dari hasil penelitian adalah (1) Agar produk variasi latihan kombinasi passing dan smash dalam permainan bola voli ini dapat digunakan oleh para pemain, serta seluruh masyarakat bola voli, sebaiknya dicetak atau diproduksi lebih banyak lagi dalam upaya mempublikasi, sosialisasi sehingga dapat diaplikasikan dalam jangkauan yang lebih luas, dan (2) Sebelum disebarluaskan sebaiknya variasi latihan kombinasi passing dan smash dalam permainan bola voliini disusun kembali untuk menjadi lebih baik, meliputi kemasan, isi dan materi.

\section{DAFTAR PUSTAKA}

Ahmadi, Nuril. (2007). Panduan Olahraga Bola Voli. Surakarta : Era Pustaka Utama

Akhmad, Imran. (2013). Dasar-Dasar Melatih Fisik Bagi Olahragawan, Medan: UNIMED Press.

Bompa, Tudor. O. (1999).Theory and Methodologi of Training. Canada : MocaicPres.

Harsono. (1988). Coaching dan Aspek-Aspek Psikologis dalam Coaching. Jakarta:

Departemen Pendidikan dan Kebudayaan

Harsuki. (2003).Pembinaan Peningkatan Kondisi Fisik, Jakarta: Koni Jakarta.

Harsuki. (2003) Perkembangan Olahraga Terkini, Jakarta, PT Raja Grafindo Persada

Kemenpora, (2009). Meningkatkan Kebugaran Jasmani Melalui Permainan \& Olahraga Bola Voli. Jakarta: GRASINDO.

Mutohir, Cholik. (2013). Permainan Bola Voli.Surabaya: Graha Media.

Mylsidayu, Apta. (2005). Ilmu Kepelatihan Dasar, Bandung.

Sajoto, M. (1988). Peningkatan dan Pembinaan Kekuatan Kondisi Fisik dalam Olahraga. Semarang: Dahara Prize.

Sudjana. (2005). Metoda Statistika. Bandung: PT. Tarsito Bandung.

Sugiono. (2008)."Metode penelitian kuantitatif, kualitatifdan $R \quad \& \quad D "$. Bandung: Alfabeta.

Yunus, M. (1992). Olahraga Pilihan Bola Voli. Jakarta : Depdikbud. 